\title{
Long-term effects of extreme weather events and eutrophication on the fish community of shallow lake Peipsi (Estonia/Russia)
}

\author{
Külli KANGUR, ${ }^{1 *}$ Peeter KANGUR,,${ }^{1}$ Kai GINTER,${ }^{1}$ Kati ORRU, ${ }^{1}$ Marina HALDNA, ${ }^{1}$ Tõnu MÖLS, ${ }^{1,2}$ \\ Andu KANGUR ${ }^{1}$ \\ ${ }^{1}$ Centre for Limnology, Institute of Agricultural and Environmental Sciences, Estonian University of Life Sciences, 61117 Rannu; \\ ${ }^{2}$ Department of Bioinformatics, Institute of Cell and Molecular Biology, University of Tartu, 51010 Riia street 23, Tartu, Estonia \\ *Corresponding author: kylli.kangur@emu.ee
}

\begin{abstract}
The fish kill in lake Peipsi (Estonia/Russia) during the extraordinarily hot summer of 2010 evoked an investigation into the effects of environmental extremes and long-term eutrophication on the fish community of the lake. Current data on lake Peipsi indicate that temperature extremes and synergistic interactions with eutrophication have led to a radical restructuring of the fish community. Commercial landings of lake smelt, Osmerus eperlanus eperlanus $m$. spirinchus (Pallas), the previous dominant species of the fish community, have decreased dramatically since the 1930s, these declines being coupled with summer heat waves coinciding with low water levels. Gradual decline in smelt stock and catches was significantly related to a decline of near-bottom oxygen conditions and to a decrease in water transparency. The first documented fish kill in 1959 occurred only in the southern, most shallow and eutrophic lake (lake Pihkva). Recently, summer fish kill have become more frequent, involving larger areas of the lake. In addition to the cold-water species, e.g. smelt and vendace Coregonus albula (L.), the abundance of bottom-dwelling fishes such as ruffe Gymnocephalus cernuus (L.) and juvenile fish have significantly decreased after the 2010 heat wave probably due to hypoxia and warm water temperatures. This study showed that fish community structure in large shallow lakes may be very vulnerable to water temperature increases, especially temperature extremes in combination with eutrophication.
\end{abstract}

Key words: climate change, eutrophication, key fish species, heat waves, large shallow lake, summer fish kills.

Received: October 2012. Accepted: March 2013.

\section{INTRODUCTION}

The stability and resilience of lake ecosystems have begun to attract considerable attention because lake ecosystems are now considered to be less predictable than previously assumed (Parmesan, 2006; Moss, 2007; Dobiesz et al., 2010). Because of the complexity of large lakes, ecosystem reactions to co-existing stressors can be nonlinear, time-lagged and partially unpredictable (Reynolds et al., 2000). Thus, complex interactions among different stressors can hamper efforts to develop accurate and precise predictions (Hart and Calhoun, 2010). Some synergies among these components of change have already been recognised (Giller et al., 2004; Woodward et al., 2010a), but overall the potential effects of interacting components of global climate change on biotic communities remain poorly understood (Durant et al., 2007; Clarke, 2009; Woodward et al., 2010b).

The lower predictability in lake ecosystems poses a risk to biodiversity, ecosystem function and services. Moreover, sudden shifts in the ecosystem induced by climate change may result in a decline and even total collapse of fish populations (Lehtonen, 1996; Jeppesen et al., 2010a, 2012). The loss of stability and resilience is especially evident in large shallow lakes, like the shallow northern temperate lake Peipsi (on the border between Estonia and Russia), that have been the centre of human activities for centuries. As fishing is an important sector of the rural economy in Peipsi region and an essential part of the lifestyle in coastal villages, it is clear that local residents are extremely interested in the stability of the fish resources of this transboundary lake. However, social and cultural issues also hamper attempts to manage the fisheries in a sustainable way (Dobiesz and Hecky, 2011).

The decline and collapse of fish populations have been frequently attributed to local human impact, including over-exploitation by fisheries and habitat degradation due to eutrophication and pollution (Allan et al., 2005). However, in addition to these local human impacts, several environmental factors (e.g. weather and ice conditions, natural water level fluctuations) are at the same time structuring these water ecosystems and influencing their development (Lehtonen, 1996; Kangur et al., 2007a; Hart and Calhoun, 2010; Elliott and Bell, 2011). Although such natural factors have less frequently been associated with the decline and collapse of fish populations, Perkins et al. (2010) and Jeppesen et al. (2010a) suggest that dramatic biotic responses to warming can arise in freshwater 
ecosystems, even to relatively small temperature gradients. Furthermore, climate change is considered to have serious impact on the stability of lake ecosystems and freshwater food webs (Durant et al., 2007; Heino et al., 2009; Perkins et al., 2010; Thackeray et al., 2010). However, the different components of climate change (e.g. temperature, hydrology and atmospheric composition) not only have effects on multiple levels of biological organisation, but also may interact with many other stressors which fresh waters are exposed to (Clarke, 2009; Woodward et al., 2010b). As in many shallow lakes, anthropogenic eutrophication remains the most serious environmental problem for lake Peipsi, triggering changes in the entire ecosystem (Kangur and Möls, 2008; Mäemets et al., 2010; Buhvestova et al., 2011; Kangur et al., 2012). However, climate change is accentuating the symptoms of eutrophication in fresh waters, especially in shallow lakes (Jeppesen et al., 2010b; Moss et al., 2011).

Because of the complexity of a large lake ecosystem, elucidation of the combined effects of environmental extremes and synergic factors (e.g. long-term eutrophication) on fish community structure is a challenging task. As these multiple stressors are often acting simultaneously, the analysis of long-term fishery datasets, coupled with hydrometeorological and water quality data, is essential for understanding the factors underlying recent developments in fish population dynamics in lakes such as lake Peipsi.

The present study investigated how extreme weather events might have affected key species of the fish community of lake Peipsi alongside the concurrent eutrophication-related degradation of lake water quality. We concentrated on lake (dwarf) smelt Osmerus eperlanus eperlanus m. spirinchus (Pallas), a small pelagic coldwater fish, which dominated the fish community of the lake in the 1930s. The abundance of smelt in commercial catches has periodically fluctuated over times, but the long-term trend (since the 1930s) is decreasing. We hypothesised that drastic reduction of the smelt population was linked to heat waves and summer temperature increases. The present study revisited an eight-decade dataset of smelt commercial catches and aimed to clarify relationships between summer water temperatures and smelt population dynamics. Specific objectives of the study were: i) to examine the fish community structure before and after the latest fish kill in lake Peipsi in the extremely hot summer of 2010; ii) to analyse differences in environmental conditions between years of fish kill and other ordinary years since the 1930s; iii) to examine the co-effect of temperature extremes and eutrophication on smelt population dynamics; and iv) to analyse the extent to which the relative abundance of fish species in commercial catches can be related to hydrological, meteorological and water quality conditions.

\section{METHODS}

\section{Study site}

Lake Peipsi $\left(57^{\circ} 51^{\prime}-59^{\circ} 01^{\prime} \mathrm{N}\right.$; $26^{\circ} 57^{\prime}-28^{\circ} 10^{\prime}$ E; Fig. 1), situated on the Estonian/Russian border, has a surface area of $3555 \mathrm{~km}^{2}$ (at the mean water level of $30 \mathrm{~m}$ asl). It is a polymictic and shallow lake with a mean depth of 7.1 $\mathrm{m}$, a maximum depth of $15.3 \mathrm{~m}$ and a hydraulic retention time about 2 years (volume $=25 \mathrm{~km}^{3}$ ). The catchment area is $47,800 \mathrm{~km}^{2}$ (including the lake surface). The total population of the basin provides ca. 1,000,000 inhabitants (Kangur et al., 2012). Lake Peipsi is elongated in the north-south direction more than $150 \mathrm{~km}$ and consists of three limnologically different parts: lake Peipsi sensu stricto (s.s.), the largest and deepest northern part; lake Lämmijärv, the middle strait-like part; and lake Pihkva, the southern and most shallow part, although together they form a single water body (Tab. 1). Lake Peipsi's water level is not regulated; however, natural water level fluctuations are considerable: an overall range of $3.04 \mathrm{~m}$ over the last 80 years, with a mean annual range of $1.15 \mathrm{~m}$ (Jaani, 2001). Situated in the north temperate region, in the transition zone between maritime and continental climate, lake Peipsi is characterised by variable weather conditions. The lake is normally covered with ice from December until April, with the onset of ice cover and melt-off varying considerably in recent years.

Lake Peipsi is eutrophic, with mean total phosphorus (TP) and total nitrogen (TN) concentrations of $48 \mathrm{mg} \mathrm{P}$ $\mathrm{m}^{-3}$ and $784 \mathrm{mg} \mathrm{N} \mathrm{m}^{-3}$, respectively, during the ice-free periods from 2006 to 2010. There is a clear south-north gradient in the lake's water quality - the nutrient concentrations are significantly lower in the northern and deepest part (lake Peipsi s.s.) than in the southern part (lake Pihkva) (Tab. 1), which receives inflow from the Velikaja river (with a catchment area of $25,600 \mathrm{~km}^{2}$ ). The growing difference in $\mathrm{P}$ concentrations between the northern and southern parts of the lake shows that the input of $\mathrm{P}$ from the south is increasing (Kangur and Möls, 2008).

Lake Peipsi is inhabited by 37 fish species (Kangur et al., 2008). Over the past eighty years, not one species has become extinct from the lake; on the other hand, there is no information about invasions of any new species into the fish community. Fish productivity of the lake has been remarkably high, e.g. compared to nearby large and shallow lake Võrtsjärv (Järvalt et al., 2004), which makes it economically important for both commercial and recreational fisheries. However, sporadic fish kills have been registered repeatedly in the lake since 1959 (Semenova, 1960) during cyanobacterial blooms in warm summers.

\section{Experimental fish surveys}

To assess the effect of summer fish kill on fish populations, the length-frequency distributions of ruffe Gymnocephalus cernuus (L.), pikeperch Sander lucioperca 


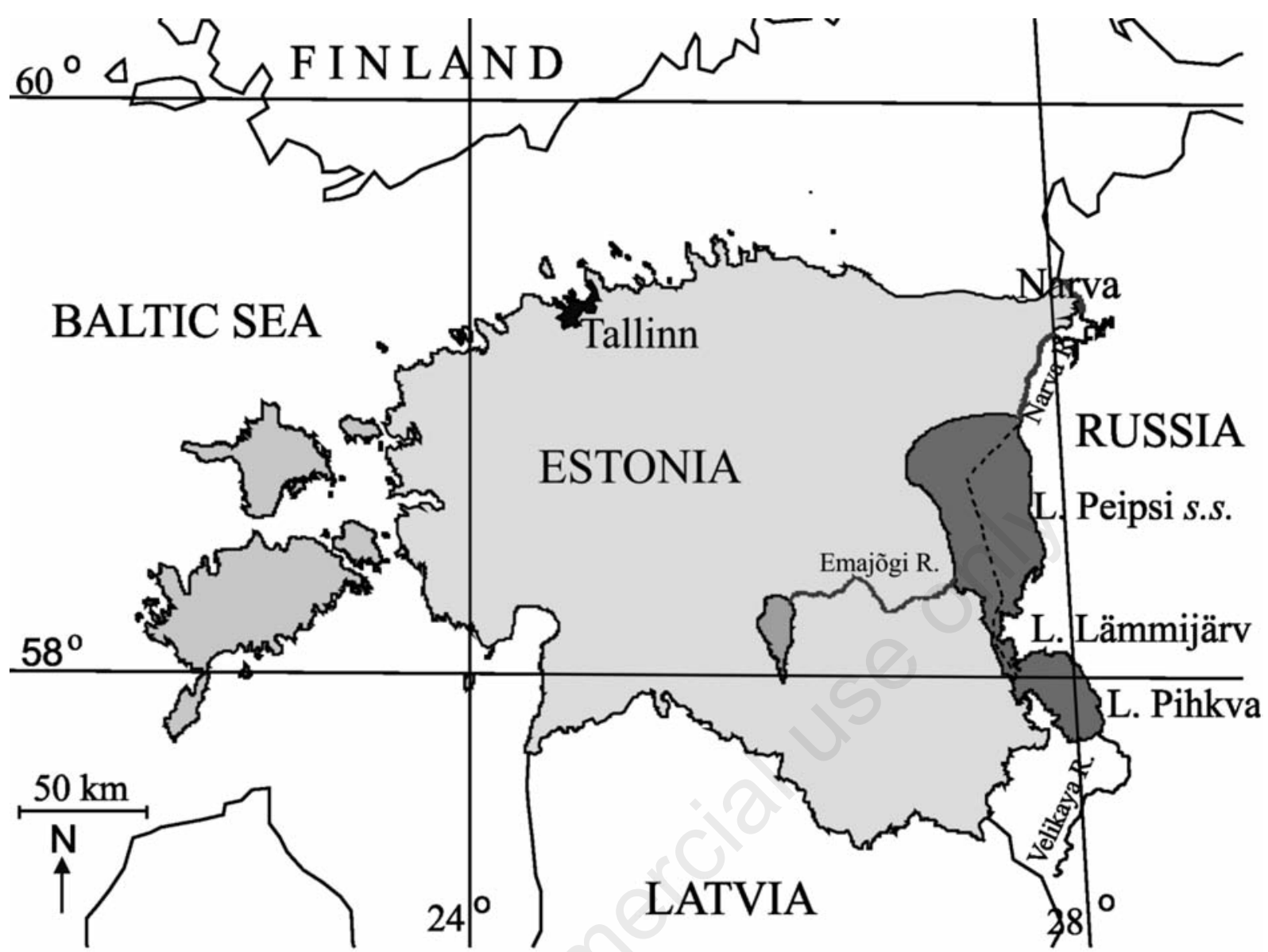

Fig. 1. Location of lake Peipsi (Estonia/Russia).

Tab. 1. Selected morphometric (Jaani, 2001), chemical and phytoplankton characteristics of lake Peipsi (Estonia/Russia) and its three parts (lake Peipsi sensu stricto, lake Lämmijärv and lake Pihkva). These estimates correspond to the open water periods (Julian days 100-310 within each year) between 2006 and 2010.

\begin{tabular}{|c|c|c|c|c|}
\hline Characteristic & $\begin{array}{c}\text { Lake } \\
\text { Peipsi s.s. }\end{array}$ & $\begin{array}{c}\text { Lake } \\
\text { Lämmijärv }\end{array}$ & $\begin{array}{l}\text { Lake } \\
\text { Pihkva }\end{array}$ & $\begin{array}{l}\text { Whole lake } \\
\text { Peipsi }\end{array}$ \\
\hline Surface area $\left(\mathrm{km}^{2}\right)$ & 2611 & 236 & 708 & 3555 \\
\hline Maximum depth (m) & 12.9 & 15.3 & 5.3 & 15.3 \\
\hline Mean depth (m) & 8.3 & 2.5 & 3.8 & 7.1 \\
\hline Water volume $\left(\mathrm{km}^{3}\right)$ & 21.79 & 0.6 & 2.68 & 25.07 \\
\hline $\mathrm{TP}\left(\mathrm{mg} \mathrm{P} \mathrm{m}^{-3}\right)$ & $\begin{array}{c}37.5^{\circ} \\
(17.1-82.0)^{\#}\end{array}$ & $\begin{array}{c}66.7^{\circ} \\
(31.9-139.6)^{\#}\end{array}$ & $\begin{array}{c}115.5^{\circ} \\
(53.1-250.8)^{\#}\end{array}$ & $\begin{array}{c}48.3^{\circ} \\
(16.7-140.2)^{\#}\end{array}$ \\
\hline $\mathrm{TN}\left(\mathrm{mg} \mathrm{N} \mathrm{m}^{-3}\right)$ & $\begin{array}{c}703^{\circ} \\
(417-1188)^{\#}\end{array}$ & $\begin{array}{c}896^{\circ} \\
(573-1401)^{\#}\end{array}$ & $\begin{array}{c}1143^{\circ} \\
(829-1577)^{\#}\end{array}$ & $\begin{array}{c}784^{\circ} \\
(439-1400)^{\#}\end{array}$ \\
\hline Chl $a$ content (mg m $\left.{ }^{-3}\right)$ & $\begin{array}{c}17.9^{\circ} \\
(5.9-53.9)^{\#}\end{array}$ & $\begin{array}{c}33.3^{\circ} \\
(13.6-81)^{\#}\end{array}$ & $\begin{array}{c}62.7^{\circ} \\
(26.2-149.6)^{\#}\end{array}$ & $\begin{array}{c}23.7^{\circ} \\
(6.4-88)^{\#}\end{array}$ \\
\hline Secchi depth (m) & $\begin{array}{c}1.8^{\circ} \\
(1.0-3.2)^{\#}\end{array}$ & $\begin{array}{c}0.95^{\circ} \\
(0.6-1.5)^{\#}\end{array}$ & $\begin{array}{c}0.7^{\circ} \\
(0.4-1.0)^{\#}\end{array}$ & $\begin{array}{c}1.4^{\circ} \\
(0.5-3.4)^{\#}\end{array}$ \\
\hline OECD (1982) classification & Eutrophic & Eutrophic/hypertrophic & Hypertrophic & Eutrophic \\
\hline
\end{tabular}

Lake Peipsi s.s., lake Peipsi sensu stricto; TP, total phosphorus; TN, total nitrogen; Chl a, Chlorophyll a; OECD, Organisation for Economic Cooperation and Development; ${ }^{\circ}$ Water quality variables are presented as geometric means; ${ }^{9} 90 \%$ tolerance limits. 
(L.), Eurasian perch Perca fluviatilis L. and roach Rutilus rutilus (L.) were analysed for one event only using data from trawl samples collected before (autumn 2009) and after (autumn 2010) the most recent fish kill in summer 2010. The age of juvenile fish was estimated from the length-frequency distribution of the $0+$ and $1+$ age group; in this way also juveniles and adults were differentiated. We also analysed the catch per unit effort (CPUE) (individuals per trawl hour) of fish species and their relative proportions (\%) of the total catch in the autumn trawl samples (September and October) in lake Peipsi in 2009 (12 samples) and 2010 (9 samples). To sample the fish, a bottom trawl (height $2 \mathrm{~m}$, width $12 \mathrm{~m}, 10-12 \mathrm{~mm}$ knotto-knot mesh size at the cod-end) was towed by a ship for 15 minutes per haul at a speed of 5.5-6.2 $\mathrm{km} \mathrm{h}^{-1}$. Trawling was carried out at noon in the pelagic zone of lake Peipsi s.s. Sampling took place over several days in September and October of both years, with each sampling excursion consisting of several trawl catches (3-4) collected at multiple locations.

\section{Commercial catch data}

To characterise long-term changes in the fish community of lake Peipsi, species composition and fish relative abundances in commercial catches were analysed in relation to environmental variables. Proper data from fish stocks beyond the past 80 years are lacking. Commercial fisheries statistics for lake Peipsi, collected from fishermen by state authorities, were available for the periods 1931-1940 (Soviet Union and Estonia), and 1950-2010 (Soviet Union, followed by Russia and Estonia). Data were unavailable for the period 1941 to 1949 due to World War II. The fish data are from a variety of fishing gear used during different time periods and localities. Main changes in fishing gears and effort since the 1930s are described by Kangur et al. (2007b). The basic fishing gear used in lake Peipsi represents local modifications of fence traps for smelt and perch as well as gill nets for pikeperch, pike and bream. Bottom seining is used mostly for pikeperch and perch. In recent times there have been no significant changes in fishing effort and fishing gears. Since the 1970s, 40 bottom seines (20 in Estonia and 20 in Russia) have been used on lake Peipsi.

\section{Environmental data}

Data on the surface water temperature in lake Peipsi, collected by the Estonian Institute of Hydrology and Meteorology mainly at Mustvee weather station $\left(58^{\circ} 50^{\prime} \mathrm{N}\right.$, $26^{\circ} 57^{\prime} \mathrm{E}$ ), are available from 1924 onwards. Limnological data for some water quality variables (e.g. water transparency as Secchi depth, dissolved oxygen concentrations, water $\mathrm{pH}$ ) are available from the 1950s. Eutrophication is characterised by changes of TP and chlorophyll $a$ (Chl- $a$ ) concentrations in different parts of the lake (data available from the 1980s only). Published data from previous studies on cyanobacteria blooms (Laugaste et al., 2001) and fish kills (Semenova, 1960; Kangur et al., 2005) were also considered. The specific methodologies used in limnological studies are well described elsewhere (Laugaste et al., 2001; Starast et al., 2001; Kangur et al., 2002, 2003; Kangur and Möls, 2008); accordingly, we have given below only a brief overview of the methods used. Most studies since 1992 have been made in the Estonian part of the lake. However, joint EstonianRussian expeditions to cover the entire lake Peipsi have been arranged regularly since 2001. Depending on the year, the number of sampling sites monitored has varied between 3 and 41 (Kangur et al., 2002). Monthly (or seasonal) water samples for routine hydrochemical analysis were obtained from both the surface layer of 0.1-1.0 m and the near-bottom layer of water ( $0.5 \mathrm{~m}$ above bottom), using a Ruttner sampler. The methods used in hydrochemical analysis are described in detail by Starast et al. (2001) and Kangur and Möls (2008).

\section{Data analysis}

The abundance of fish species in trawl samples (CPUE) was tested with Wilcox test in R (R Development Core Team, 2010). The frequency of fish species in trawl samples before (in autumn 2009) and after (in autumn 2010) the summer fish kill in 2010 was examined using the chi-square $\left(\chi^{2}\right)$ test in R. For testing and estimating the changes in percentages of different length classes (based on $1 \mathrm{~cm}$ class intervals) of fish in trawl samples before and after the fish kill, the SAS generalised linear models (GENMOD) procedure with binomial distribution and logit link function was used (SAS Institute Inc., 2008).

To estimate the long-term changes in water $\mathrm{pH}$ and transparency of lake Peipsi, a large linear model, using the SAS/STAT package (SAS Institute Inc., 2008) was developed based on a general model tailored for lake Peipsi and lake IJsselmeer that has been previously tested for an advanced analysis of long-term hydrochemical and hydrobiological data (Möls, 2005; Lammens et al., 2007). This model contained 60 terms, including six terms of Gaussian presentation of the year number, three terms of $\beta$-transformations of the Julian day number, the scaled geographical coordinates and several terms presenting interactions between these terms (determination coefficients $\mathrm{R}^{2}$ for $\mathrm{pH}$ and Secchi depth models were 0.48 and 0.64 , respectively).

Long-term changes in water temperature were analysed using the GLM procedure in SAS with a cubic polynomial model. The $95 \%$ confidence limits for the predicted values of parameters were estimated in SAS assuming normality of model residuals. The pre-determined temperature parameters lowlevel and highlevel were set 
at 1 and $20^{\circ} \mathrm{C}$, respectively. Both ice formation and melt off in lake Peipsi usually take 2-3 weeks but can last up to a month. Therefore, the duration of the ice-free period was taken conventionally as equal to the number of days when the temperature was $>1{ }^{\circ} \mathrm{C}$ (lowlevel). Water temperature dynamics of a year was characterised using the following parameters (Tab. 2): duration of ice-free period (openwater, $\geq 1{ }^{\circ} \mathrm{C}$ ), maximum ${ }^{\circ} \mathrm{C}$ of a year (realmaxtemp), the $1^{\text {st }}$ day when temperature exceeded $20^{\circ} \mathrm{C}$, highlevel (i.e. firsthightempday), the number of days when temperature exceeded $20^{\circ} \mathrm{C}$ (highdays), and the number of degrees $>20^{\circ} \mathrm{C}$ (degree-days) calculated for each day and over the year $\left(Q\right.$ sum $\left.>20^{\circ} \mathrm{C}\right)$. Differences between the water temperature parameters in the years of fish kill $(1959,1972,1988,2002$ and 2010) and other ordinary years since the 1930s (periods presented in Tab. 2) were estimated using ANOVA Tukey test. In the statistical tests the level of significance $(\alpha)$ was set to 0.01 .

\section{RESULTS}

\section{Fish community structure before and after the fish kill in $\mathbf{2 0 1 0}$}

The mean abundance of fish species (CPUE) (individuals per trawl hour) and their relative proportions (\%) in the autumn trawl samples differed significantly before and after the latest fish kill (Tab. 3). In 2010, the summer fish kill had no significant effect on juvenile roach but decreased significantly $(\mathrm{P}<0.0001)$ the number of age $0+$ pikeperch, $0+$ perch and $0+$ ruffe relative to the previous year data (Fig. 2). The estimated change in percentages of different length classes of a certain fish species in trawl samples before and after the fish kill was for ruffe - from 71 to $26 \%(\mathrm{P}=0.0029)$, for pikeperch - from 89 to $0 \%$ $(\mathrm{P}<0.0001)$, and for perch - from 28 to $0 \%(\mathrm{P}=0.0026)$. The numbers of adult ruffe $(8-15 \mathrm{~cm})$ also decreased significantly $(\mathrm{P}<0.0001)$. Similarly, according to the $\chi^{2}$ test

Tab. 2. Characteristics of selected water temperature variables (see text for definitions) in lake Peipsi (Estonia/Russia) for the periods 1931-1960, 1961-1985, 1986-2010 and for the years when the fish kills have occurred.

\begin{tabular}{|c|c|c|c|c|c|c|c|c|c|c|c|c|c|c|c|c|c|}
\hline \multirow{3}{*}{$\begin{array}{l}\text { Variable } \\
\text { Openwater (days) }\end{array}$} & \multicolumn{4}{|c|}{$1931-1960$} & \multicolumn{4}{|c|}{ 1961-1985 } & \multicolumn{4}{|c|}{ 1986-2010 } & \multicolumn{5}{|c|}{ Values in the years of fish kill } \\
\hline & Mean & Min & Max & $\begin{array}{c}\mathrm{S} \\
(\mathrm{LCL}, \mathrm{UCL})\end{array}$ & Mean & Min & Max & $\mathrm{S}$ & Mean & Min & Max & $\mathrm{S}$ & 1959 & 1972 & 1988 & 2002 & 2010 \\
\hline & 201 & 186 & 222 & ns & 206 & 194 & 222 & ns & 209 & 189 & 234 & ns & 201 & 196 & 198 & 204 & 197 \\
\hline $\begin{array}{l}\text { Realmaxtemp }{ }^{*} \\
\left({ }^{\circ} \mathrm{C}\right)\end{array}$ & 23.4 & 18.7 & 28.4 & $\begin{array}{c}0.2 \\
(0.1,0.3)\end{array}$ & 25.3 & 22.3 & 28.0 & ns & 25.0 & 20.6 & 28.8 & ns & 28.4 & 28.0 & 28.8 & 26.6 & 26.3 \\
\hline $\begin{array}{l}\text { Firsthightempday } \\
\text { (Julian day) }\end{array}$ & 160 & 127 & 190 & $\begin{array}{c}-1.4 \\
(-1.9,-0.9)\end{array}$ & 145 & 128 & 167 & ns & 155 & 127 & 194 & ns & 136 & 141 & 145 & 150 & 137 \\
\hline $\begin{array}{l}\text { Highdays }{ }^{*} \\
\text { (days) }\end{array}$ & 70.8 & 33 & 107 & $\begin{array}{c}1.3 \\
(0.6,2.0)\end{array}$ & 83.9 & 46 & 102 & $\mathrm{~ns}$ & 79.5 & 48 & 110 & $\mathrm{~ns}$ & 80 & 93 & 90 & 110 & 69 \\
\hline Qsum $>20^{\circ} \mathrm{C}^{*}$ & 50.9 & 0.4 & 174.8 & $\begin{array}{c}3.1 \\
(1.0,5.2)\end{array}$ & 86.1 & 9.4 & 268.2 & ns & 96.4 & 1.9 & 231.4 & $\mathrm{~ns}$ & 174.8 & 268.2 & 231.4 & 208.1 & 152.2 \\
\hline
\end{tabular}

Mean, Min and Max, mean, minimum and maximum descriptive statistics for the indicated period; $S$, slope of the regression line for the period, with $95 \%$ confidence limits if significant at $P<0.05 ;$ LCL, lower confidence limit; UCL, upper confidence limit; ns, not significant. *Variables that have changed significantly $\left(P<10^{-6}\right)$ in the sense of a cubic polynomial regression over the whole period of 1931-2010.

Tab. 3. The mean abundance of fish species and their proportion (\%) of the total catch according to the autumn (September and October) trawls in lake Peipsi (Estonia/Russia) in 2009 and 2010.

\begin{tabular}{lccccc}
\hline Fish species & 2009 CPUE $(\%)^{\circ}$ & \multicolumn{3}{c}{2010 CPUE $(\%)^{\circ}$} & P \\
\hline Ruffe & $3078 \pm 771$ & 64.1 & $532 \pm 152$ & 18.0 & 0.00023 \\
Eurasian perch & $685 \pm 217$ & 14.2 & $1201 \pm 147$ & 40.7 & $<0.0001$ \\
Pikeperch & $965 \pm 510$ & 20.1 & $690 \pm 198$ & 23.4 & $<0.0001$ \\
Roach & $29.0 \pm 15.6$ & 0.6 & $45.6 \pm 9.5$ & 1.6 & 0.13 \\
Common bream & $39.1 \pm 12.7$ & 0.8 & $469 \pm 85$ & 15.9 & $<0.0001$ \\
Lake smelt & $2.6 \pm 1.3$ & 0.1 & $1.2 \pm 1.2$ & $<0.1$ & 0.13 \\
Northern pike (Esox lucius L.) & $2.2 \pm 0.7$ & $<0.1$ & $6.2 \pm 1.3$ & 0.2 & 0.013 \\
Burbot & $2.7 \pm 1.5$ & 0.1 & $5.2 \pm 1.7$ & 0.2 & 0.07 \\
Peipsi whitefish & $1.3 \pm 1.0$ & $<0.1$ & $0.4 \pm 0.4$ & $<0.1$ & 0.32 \\
\hline Total catch & $4802.0 \pm 986.5$ & 100 & $2950.7 \pm 304.7$ & 100 & $<0.0001$
\end{tabular}

CPUE, catch per unit effort; $P, P$ value indicating the significance of difference between the mean abundance of fish species in the two years according to the Wilcox test. ${ }^{\circ}$ Individuals per trawl hour \pm standard error. 
roach showed the smallest decrease in CPUE, whereas considerable decreases were observed in $0+$ pikeperch $(\approx 47), 0+$ perch $(31)$ and $0+$ ruffe $(10)$, with an approximate 2 decrease in the CPUE of adult ruffe.

\section{Trends in commercial catch and shift in fish community}

Commercial fishery statistics reveal remarkable changes in the fish community composition in lake Peipsi since the 1930s, with the mean commercial fish catch declining $\left(\mathrm{R}^{2}=0.36, \mathrm{~F}_{1,66}=37.56, \mathrm{P}<0.0001\right)$ from 11,650 tons $\left(33 \mathrm{~kg} \mathrm{ha}^{-1}\right)$ in 1931-1940 to 5408 tons $\left(16 \mathrm{~kg} \mathrm{ha}^{-1}\right)$ in 2005-2010. This decline in total catch is positively correlated (Pearson correlation $\mathrm{R}=0.65, \mathrm{P}<0.0001$ ) with a decline in the smelt catch $\left(\mathrm{R}^{2}=0.32, \mathrm{~F}_{1,68}=31.84, \mathrm{P}<0.0001\right)$. Smelt has been the main planktivore and the most important commercial catch species by weight in lake Peipsi (Fig. 3). In recent years, smelt abundance has declined and since 2007, smelt has disappeared from the commercial fish catches. In the 1930s, the catches were dominated by smelt ( $43 \%$ of total catch), roach $(16 \%)$, perch $(7 \%)$ and common bream Abramis brama (L.) (7\%), but in 2005-2010 they consisted mainly of pikeperch (27\%), perch $(24 \%)$, bream $(20 \%)$, and roach $(14 \%)$. There are shifts in feeding guilds of fish (Fig. 4). This concurrent increase in piscivores and decrease in planktivores in the total catch (Fig. 4) reflects a shift away from cold-adapted, typically oligotrophic, species [smelt, vendace Coregonus albula (L.), Peipsi whitefish Coregonus lavaretus maraenoides Poljakow, burbot Lota lota (L.)] towards warm-adapted, eutrophication-tolerant species (pikeperch, bream) as the fish habitat has changed.

\section{Deterioration of fish habitat}

Limnological time-series data from the 1950 s to 2010 indicate deterioration in lake water quality and fish habitat.
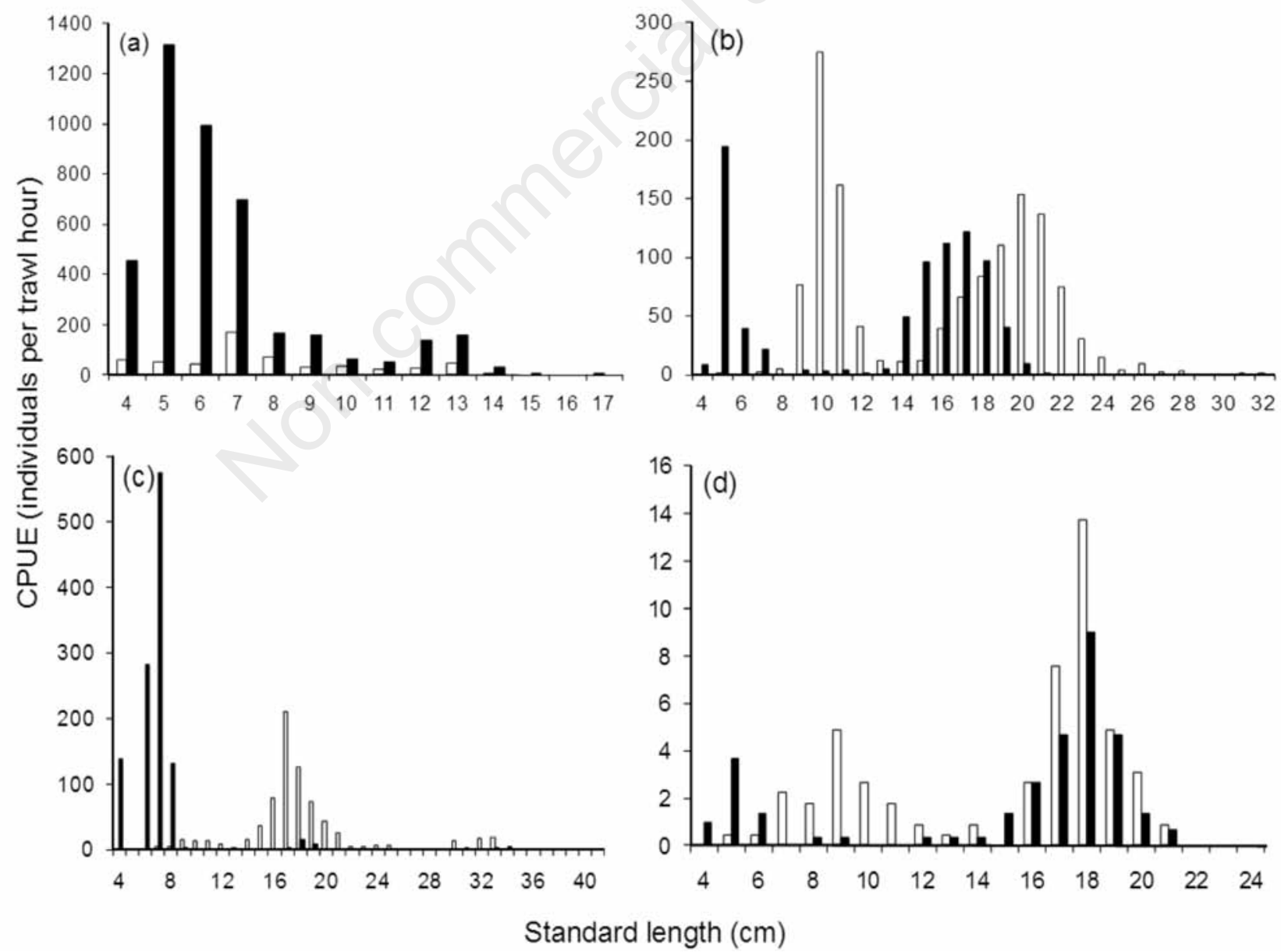

Fig. 2. The catch per unit effort of ruffe (a), perch (b), pikeperch (c) and roach (d) before (in autumn 2009; black bars) and after (in autumn 2010; white bars) the fish kill. 


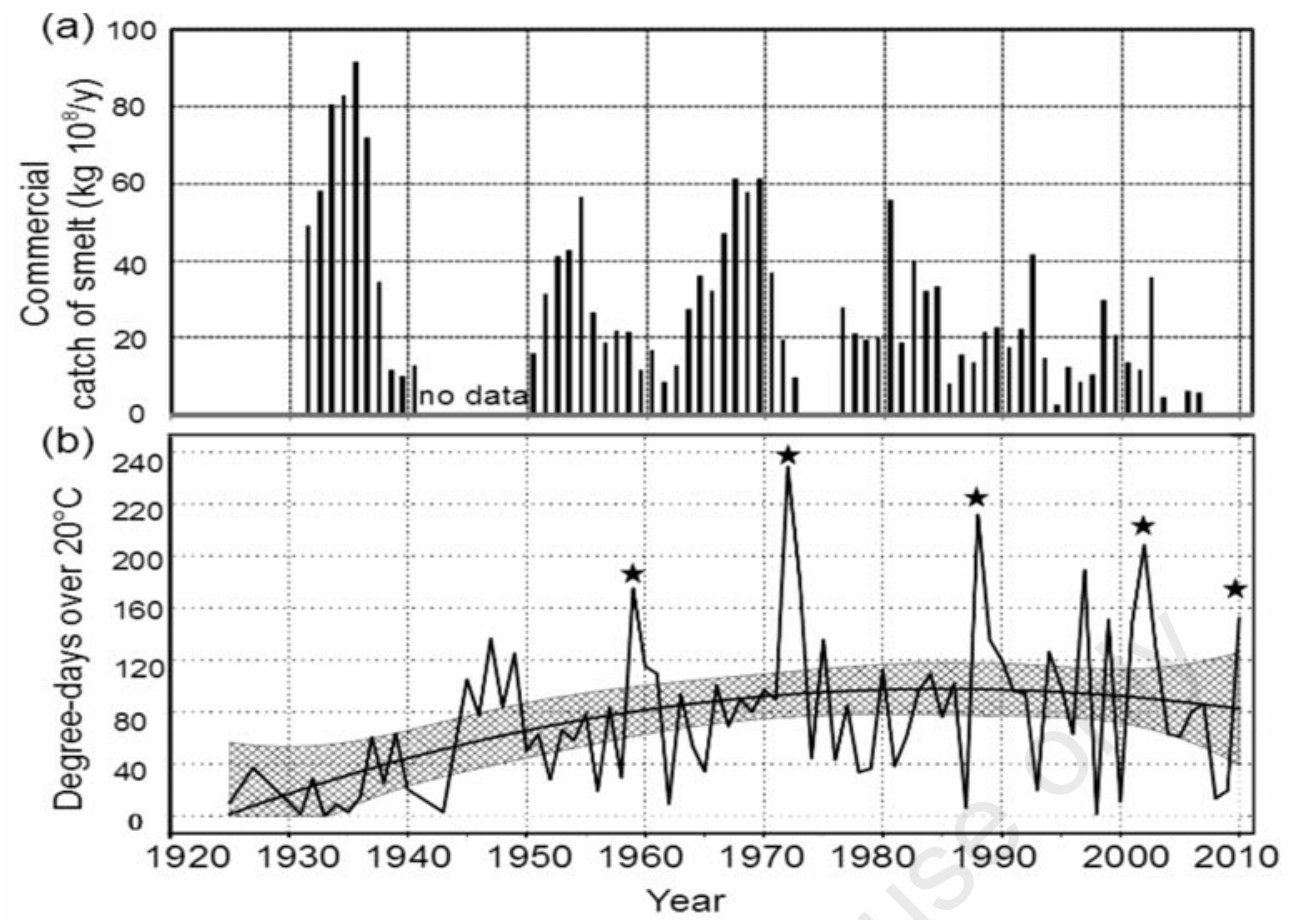

Fig. 3. (a) Changes in commercial catches of smelt; (b) and the sum of water temperature degree-days over $20^{\circ} \mathrm{C}$ during a year in lake Peipsi (Estonia/Russia) from 1925 to 2010 . Fish kills during the hottest summers are marked with stars. The smooth line shows the predicted mean values and the shaded area shows $95 \%$ confidence limits of the predicted values.

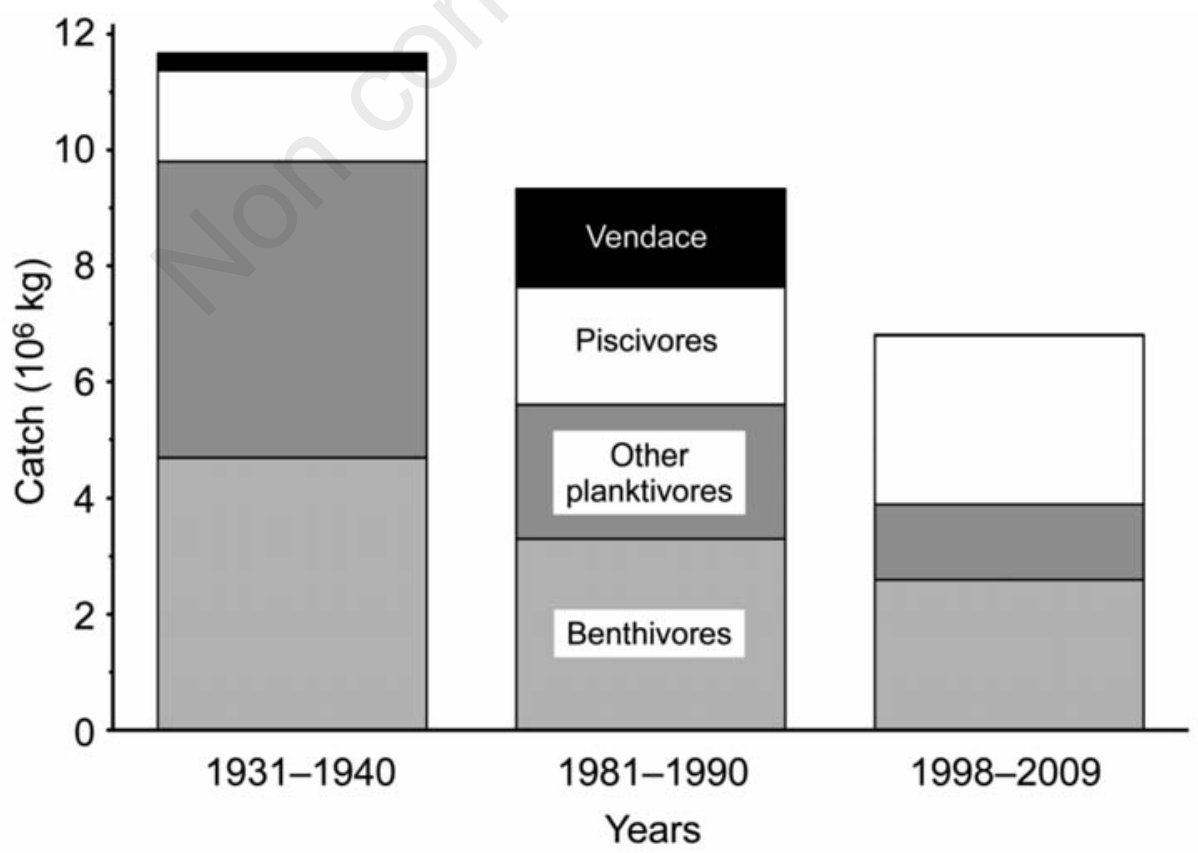

Fig. 4. The proportion of different trophic groups of fish species in commercial catches from lake Peipsi (Estonia/Russia): benthivores (common bream, ruffe), planktivores (Peipsi whitefish, smelt, juvenile fish) and piscivores (pikeperch, northern pike Esox lucius L., Eurasian perch, burbot). 
Mean Secchi depth in the ice-free period (April-November) has decreased considerably $\left(\mathrm{R}^{2}=0.54, \quad \mathrm{~F}_{1,58}=67.48\right.$, $\mathrm{P}<0.0001)$ in the past five decades, from $2.3 \mathrm{~m}(90 \%$ tolerance limits $1.2-4.5 \mathrm{~m})$ in $1950-1955$ to $1.4 \mathrm{~m}(90 \%$ tolerance limits 0.6-3.4 m) in 2006-2010 in lake Peipsi. Mean oxygen concentrations between May and October in the near-bottom water $(0.5 \mathrm{~m}$ above the sediment $)$ have decreased significantly $\left(\mathrm{R}^{2}=0.18, \mathrm{~F}_{1,59}=12.98, \mathrm{P}<0.001\right)$ from $10.4 \mathrm{mg} \mathrm{L}^{-1}\left(90 \%\right.$ tolerance limits $\left.7.1-15.3 \mathrm{mg} \mathrm{L}^{-1}\right)$ in $1950-1955$ to $8.1 \mathrm{mg} \mathrm{L}^{-1}$ (90\% tolerance limits $2.7-23.9 \mathrm{mg}$ $\mathrm{L}^{-1}$ ) in 2006-2010, with a corresponding, and even greater, decrease $\left(\mathrm{R}^{2}=0.35, \mathrm{~F}_{1,59}=31.82, \mathrm{P}<0.0001\right)$ in the near-bottom minimum oxygen concentration (from 7.1 to $0.6 \mathrm{mg}$ $\mathrm{L}^{-1}$ ) during the same intervals. Mean $\mathrm{pH}$ during the ice-free period (April-November) in lake Peipsi increased significantly $\left(\mathrm{R}^{2}=0.39, \mathrm{~F}_{1,58}=37.21, \mathrm{P}<0.0001\right)$, from $8.17(90 \%$ tolerance limits $=7.83-8.52)$ to 8.45 (7.89-9.02) for the same intervals, with water transparency decreases and $\mathrm{pH}$ increases most noticeable in lake Peipsi s.s., the clearest part of the lake (Fig. 5). Changes in water quality can be related to the long-term dynamics of smelt population. Decline in smelt commercial catches was significantly related with a decline of near-bottom oxygen conditions $\left(\mathrm{R}^{2}=0.18\right.$, $\left.\mathrm{F}_{1,57}=12.27, \mathrm{P}<0.0009\right)$ and with a decrease of Secchi depth $\left(\mathrm{R}^{2}=0.17, \mathrm{~F}_{1,57}=11.44, \mathrm{P}<0.0013\right)$, whereas an increase of water $\mathrm{pH}$ had limited influence $\left(\mathrm{R}^{2}=0.12, \mathrm{~F}_{1,58}=7.92\right.$, $\mathrm{P}<0.0067$ ) on stock dynamics.

The ongoing eutrophication of lake Peipsi is evident from the prominent lake-wide gradients of nutrient concentrations: lake Peipsi had a significantly lower nutrient load than lake Pihkva (Tab. 1). Total phosphorus concentrations have approximately doubled (from 61 to $115 \mathrm{mg}$ $\mathrm{P} \mathrm{m}^{-3}$ between 1985 and 2010), but Chl- $a$ concentrations increased three-fold (from 20.5 to $62.7 \mathrm{mg} \mathrm{m}^{-3}$ from 1985 to 2010), indicating an increase in the trophic state of lake
Pihkva over the last two decades. During the same interval, TP concentrations increased in lake Lämmijärv from 54 to $67 \mathrm{mg} \mathrm{P} \mathrm{m}^{-3}$ and in lake Peipsi from 30 to $37 \mathrm{mg} \mathrm{P}$ $\mathrm{m}^{-3}$. In accordance with this lake-wide eutrophication gradient, the first fish kill occurred only in the southern, most shallow and eutrophic lake (lake Pihkva). However, the later fish kills expanded to the whole lake.

\section{Trends in summer water temperature}

Water temperature during the ice-free period was highly variable over the long-term (Tab. 2), though the length of the ice-free period did not change significantly, even though the ice-melt dates have occurred earlier. In spring firsthightempday advanced significantly $(\mathrm{P}<0.0001)$ over the past eight decades, even though early warming in spring was more common from 1960 to 1980 (Tab. 2). The number of highdays and $Q$ sum $>20^{\circ} \mathrm{C}$ both increased (Tab. 2; Fig. 3). Furthermore, extraordinarily hot summers (water temperatures $>20^{\circ} \mathrm{C}$ ) for long periods (up to 110 days in 2002) have become more frequent. The highest summer realmaxtemp and $Q$ sum $>20^{\circ} \mathrm{C}$ values coincided with mass fish mortalities (Fig. 4). Although the yearly maximum water temperature in summer has increased over the long-term, the year-to-year variability in maximum temperature was high and exceeded $8^{\circ} \mathrm{C}$. In some years, water temperature in lake Peipsi barely reached $20^{\circ} \mathrm{C}$, but the highest water temperature during $1924-2010$ was $28.8^{\circ} \mathrm{C}$ on 27 June 1988. In the most recent summer fish kill (2010), maximum water temperature in lake Peipsi was $26.3^{\circ} \mathrm{C}$, in contrast to $22.1^{\circ} \mathrm{C}$ in 2009 . According to the ANOVA results, the patterns of summer water temperature in the years of fish kill differed significantly from other ordinary years since the 1930s without massive fish kills. In the years of fish kill, the maximum summer water temperature was on average

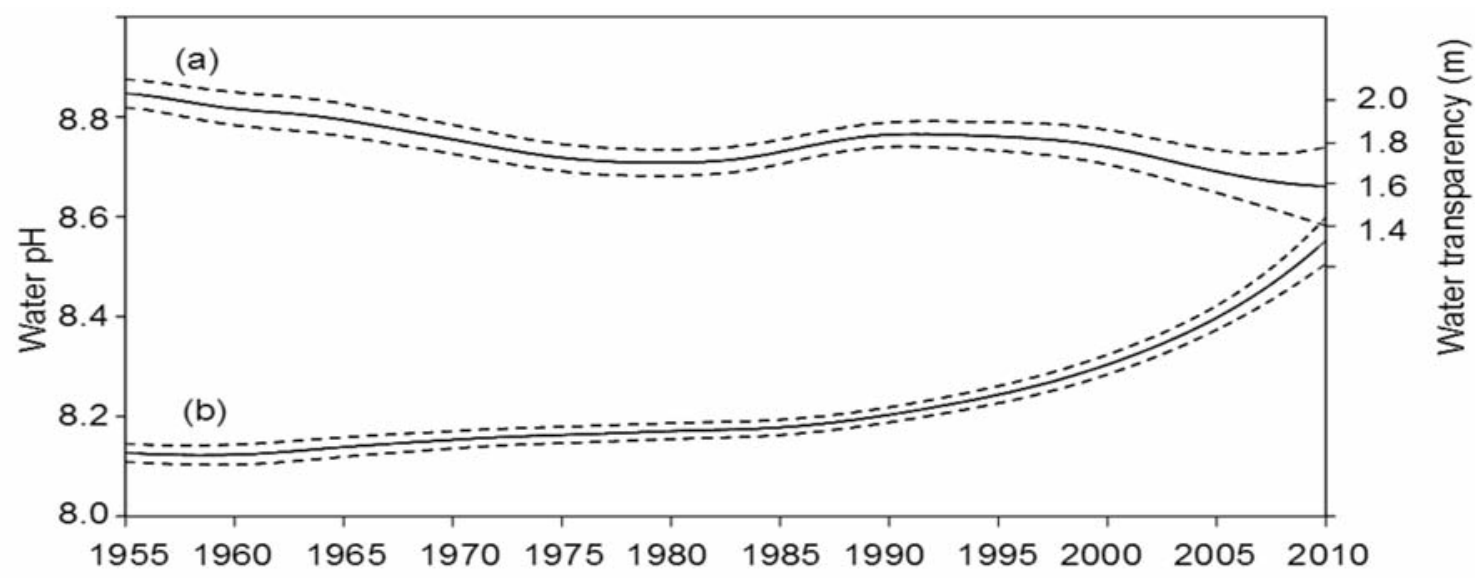

Fig. 5. (a) Changes in water transparency (Secchi depth) (m); and (b) water pH in lake Peipsi (Estonia/Russia) from 1955 to 2010 according to the generalised linear model. The dotted lines show the $95 \%$ confidence limits of the model. 
$3.2^{\circ} \mathrm{C}$ higher $\left(\mathrm{R}^{2}=0.28, \mathrm{~F}_{3,75}=9.99, \mathrm{P}=0.0001\right)$, highdays lasted on average 24.6 days longer $\left(\mathrm{R}^{2}=0.15, \mathrm{~F}_{3,75} 4.47\right.$, $\mathrm{P}=0.006$ ), and accordingly, $Q$ sum $>20^{\circ} \mathrm{C}$ was 138 degreedays higher $\left(\mathrm{R}^{2}=0.42, \mathrm{~F}_{3,75}=18.2, \mathrm{P}<0.0001\right)$ than in other ordinary years.

\section{Co-effects of temperature extremes and eutrophica- tion on the fish community}

The data indicate that eutrophication has increased the effect of temperature extremes. In hot summers (water temperature up to $26-28^{\circ} \mathrm{C}$ ) with calm weather, cyanobacterial blooms and fish kills co-occurred during the past five decades (Fig. 3). Although mass growth of cyanobacteria has been documented in lake Peipsi since the $19^{\text {th }}$ century, eutrophication appears to have increased biomass of cyanobacteria and algal bloom intensity (Laugaste et al., 2001) with accompanying fish kills. In summer 1959, the first large-scale smelt mortality was described during a bloom of Aphanizomenon sp. (Semenova, 1960), which was restricted to the southern, most shallow, and eutrophic lake, lake Pihkva (Tab. 1). The next massive smelt kill occurred in summer 1972, during a calm, warm period due to cyanobacteria blooming affecting the entire lake. In the following years (1973-1974), no smelt were caught (Fig. 3), which was followed in the next 2-3 years by a quick recovery in the smelt population. However, thereafter the smelt population suffered from long-term negative effects due to subsequent hot summers with cyanobacterial blooms. Data from trawl samples in recent years have revealed that smelt abundance have declined to a historically low level, with few specimens captured (Tab. 3) and smelt have also disappeared from commercial catches (Fig. 3). Furthermore, after the extreme weather and fish kill events in 1988 (Fig. 3), the vendace population collapsed and this has not yet returned to its previous levels.

Recently, summer fish kill events have become frequent, involving larger areas of lake Peipsi. During the latest fish kills in the summers of 2002 and 2010 (Fig. 3), in addition to adult cold-water fish (smelt, vendace), also juvenile fish and other fish species, especially bottomdwelling fish such as ruffe, were seriously affected by hypoxia and warm water temperatures. During the most recent fish kill, we measured one of the lowest dissolved oxygen concentrations of $1.4 \mathrm{mg} \mathrm{L}^{-1}$ (10 August 2010) in the near-bottom water. In the 2002, the lowest oxygen concentration in the ice-free period $\left(2 \mathrm{mg} \mathrm{L}^{-1}\right)$ was recorded during a heat wave in the early morning of 16 August 2002 just before sunrise (Kangur et al., 2005). Mass fish kills have followed the same pattern as diminishing oxygen concentrations, these occurring mainly at night or during the early morning hours. Other evidence for hypoxia in lake Peipsi was abnormal fish behaviour. Ruffe, which usually dwell on the bottom, were ascending from the bottom to the surface water, moving slowly and gulping for air. In both summers of 2002 and 2010, thousands of dead fish, mostly ruffe, but also some other fish species (pikeperch and perch) were observed on the shore.

\section{DISCUSSION}

According to the current investigation, environmental extremes and concurrent eutrophication can stimulate radical restructuring of the fish community in large shallow lakes like Peipsi. These coexisting stressors can influence the recruitment of fish: after the extremely warm weather and fish kill events in 2010, the number of age 0+ fish was significantly lower in trawl samples than in the previous year. However, there may be also other reasons (e.g. diseases, mismatch in food supply, species invasions) for decrease in the number of age $0+$ fish, and therefore further long-term studies are needed. Importantly, any abrupt increase or decrease in juvenile fish numbers can significantly affect the whole lake ecosystem through cascading effects of predation (Carpenter and Kitchell, 1993; Ginter et al., 2011), and this is especially true in cold-temperate lakes (Danger et al., 2009; Jeppesen et al., 2010a). Moreover, as the abundance of juveniles of pikeperch and perch have decreased after summer fish kill, the populations of adult piscivores may be seriously affected, because the size and structure of their populations is strongly dependent on their success at the juvenile stage (van Densen 1985; Persson and Brönmark, 2008; Ginter et al., 2011).

During the most recent decades, the fish habitat in lake Peipsi has considerably changed, as both nutrient concentrations and summer water temperature have increased while oxygen level has decreased. Thus, a combined impact of climate change and eutrophication (Moss et al., 2011) can be expected to continue in this shallow lake. Abundance changes in the fish species populations have gone in opposite directions for cold-adapted as compared with warm-adapted species, which is, according to Parmesan and Yohe (2003), a diagnostic fingerprint of climate change impact. Lake Peipsi is no longer a suitable habitat for smelt, vendace, whitefish and burbot, all of which prefer colder oligotrophic water richer in oxygen. As lake Peipsi is shallow and usually well mixed in summer, there is no coolwater refuge for these cold-water fish. However, the warmer and more eutrophic conditions are suitable for pikeperch and bream, which are generally classified as warm-tolerant species favoured by eutrophic conditions (Lehtonen, 1996; Jeppesen et al., 2000). According to the current study, roach and bream have been the least affected by temperature extremes. Therefore, cyprinids may be favoured at the expense of coregonids in lake Peipsi, as has been found in many other European lakes (Lehtonen, 1996; Lammens, 2001). As the warming trends are projected to intensify (IPCC, 2007), major shifts in the fish community, e.g. a shift towards higher dominance of eurythermal species (Jeppesen et al., 2012) is expected. 
Continued climate change is suggested to weaken the resilience of many ecosystems (including lakes) leading to sudden re-organisations of communities (Scheffer and Carpenter, 2003). In lake Peipsi, the effects of eutrophication have increased dramatically in hot and dry summers, when water levels have decreased sharply and water quality variables (e.g. water transparency, nutrients and dissolved oxygen concentrations) have indicated the worsening of the lake's ecological health (Kangur et al., 2003, 2005). Hence, its status can shift abruptly in response to drought, causing fish kills. Recent warming in summertime (together with severe heat waves) and nutrient enrichment of lake Peipsi are acting in the same direction: both are increasing cyanobacterial blooms and the probability of fish kills, both of which have occurred in larger areas of the lake, including the deepest parts. Thus, eutrophication and temperature extremes may have amplified the effect of each other in shallow lakes.

Environmental extremes and concurrent eutrophication has led to the decline of smelt abundance to a historically low level. Our study indicates that smelt, a small shoaling surface fish, reacts strongly and quickly to environmental extremes. Its abundance has fluctuated periodically, within a gradual decline on a long-term scale. This pattern follows that of increasing summer mean and maximum water temperatures, which are acting in concert with a eutrophication-related decline of oxygen content. The decline of smelt has been particularly high in the years with heat waves. Using regression analysis Kangur et al. (2007a) have found a strong negative effect of high water temperature $\left(\geq 20^{\circ} \mathrm{C}\right)$ on the abundance of the smelt population with a lag of 1 and 2 years. A relatively short life span (in lake Peipsi mainly about two years in duration), together with early reproduction, and high fecundity make the smelt population unstable and vulnerable to changes in the environment. Our results confirm that small cold-tolerant and short generation time species like smelt will suffer most from increasing exposures to summer heat (Pörtner and Peck, 2010; Thackeray et al., 2010) while large-sized and long-lived species are generally deemed to be more resilient when exposed to unpredictable environments (Woodward et al., 2010b). Moreover, if current conditions prevail, the recovery of the smelt population is unlikely in lake Peipsi. Other coldstenothermal specialists are also close to their physiological limits and may be driven to extinction as temperatures continue to rise (Jeppesen et al., 2010a; Perkins et al., 2010; Woodward et al., 2010b). Thus, extreme weather events and concurrent eutrophication can cause long-lasting and perhaps irreversible changes in the fish community composition of shallow lakes.

Recently, besides the effects on cold-water fish (smelt, vendace), benthic fish such as ruffe were also seriously affected by hypoxia and suboptimally high water temper- atures during heat waves and cyanobacterial blooms. Similarly, Arend et al. (2011) found that among fish species, the effect of hypoxia on annual habitat quality was more pronounced for cold-water species and for benthic species. The number of ruffe have decreased substantially after the fish kill because the recent fish kills have involved the entire lake Peipsi and bottom-dwelling fish have had no refuge from the deoxygenation occurring in still, warm summer nights.

\section{CONCLUSIONS}

This study showed that gradual long-term shifts in the fish community of lake Peipsi and abrupt dramatic events (fish kills) are tightly linked as both processes represent an outcome of concurring climate change and eutrophication.

\section{ACKNOWLEDGMENTS}

We thank the anonymous reviewers and Dr. Franz Hölker for helpful comments that improved the manuscript. The research was supported by the Estonian Science Foundation (grant No. 6820 and 7643) and the Estonian Target Financed Projects SF0170006s 08 and SF0180026s 09. Additionally, we gratefully acknowledge Dr. Renee Miller (UK) for language editing.

\section{REFERENCES}

Allan JD, Abell R, Hogan Z, Revenga C, Taylor BW, Welcomme RL, Winemiller K, 2005. Overfishing of inland waters. Bioscience 55:1041-1051.

Arend K, Beletsky D, DePinto JV, Ludsin SA, Roberts JJ, Rucinski DK, Scavia D, Schwab DJ, Höök TO, 2011. Seasonal and interannual effects of hypoxia on fish habitat quality in central lake Erie. Freshwater Biol. 56:366-383.

Buhvestova O, Kangur K, Haldna M, Möls T, 2011. Nitrogen and phosphorus in Estonian rivers discharging to lake Peipsi: estimation of loads and seasonal and spatial distribution of concentrations. Est. J. Ecol. 60:18-38.

Carpenter SR, Kitchell JF, 1993. The trophic cascade in lakes. Cambridge University Press, Cambridge: 399 pp.

Clarke SJ, 2009. Adaption to climate change: implications for freshwater biodiversity and management in the UK. Freshw. Rev. 2:51-64.

Danger M, Lacroix G, Kâ S, Ndour EH, Corbin D, Lazzaro X, 2009. Food-web structure and functioning of temperate and tropical lakes: a stoichiometric viewpoint. Ann. Limnol.-Int. J. Lim. 45:11-21.

Dobiesz ED, Hecky RE, 2011. Ecosystem health of the world's great lakes and its influence on the sustainability of their fisheries, p. 51-83. In: Sustainable fisheries: multi-level approaches to a global problem. American Fisheries Society Publ.

Dobiesz ED, Hecky RE, Johnson TB, Sarvala J, Dettmers JM, Lehtiniemi M, Rudstam LG, Madenjian CP, Witte F, 2010. Metrics of ecosystem status for large aquatic systems: a global comparison. J. Great Lakes Res. 36:123-138.

Durant JM, Hjermann DO, Ottersen G, Stenseth NC, 2007. Cli- 
mate and the match or mismatch between predator requirements and resource availability. Climate Res. 33:271-283.

Elliott JA, Bell VA, 2011. Predicting the potential long-term influence of climate change on vendace (Coregonus albula) in Bassenthwaite lake, U.K. Freshwater Biol. 56:395-405.

Giller PS, Hillebrand H, Berninger U-G, Gessner MO, Hawkins $\mathrm{S}$, Inchausti P, Inglis C, Leslie H, Malmqvist B, Monaghan MT, Morin PJ, O'Mullan G, 2004. Biodiversity effects on ecosystem functioning: emerging issues and their experimental test in aquatic environments. Oikos 104:423-436.

Ginter K, Kangur K, Kangur A, Kangur P, Haldna M, 2011. Diet patterns and ontogenetic diet shift of pikeperch, Sander lucioperca (L.) fry in lakes Peipsi and Võrtsjärv (Estonia). Hydrobiologia 660:79-91.

Hart DD, Calhoun AJK, 2010. Rethinking the role of ecological research in the sustainable management of freshwater ecosystems. Freshwater Biol. 55:258-269.

Heino J, Virkkala R, Toivonen H, 2009. Climate change and freshwater biodiversity: detected patterns, future trends and adaptations in northern regions. Biol. Rev. 84:39-54.

IPCC, 2007. Summary of policymakers, p. 7-22. In: M.L. Parry, O.F. Canziani, J.P. Palutikof, P.J. van der Linden and C.E. Hanson (eds.), Climate change 2007: impacts, adaptation and vulnerability. Contribution of working group II to the Fourth assessment report of the Intergovernmental Panel on Climate Change. Cambridge University Press.

Jaani A, 2001. The location, size and general characterisation of lake Peipsi and its catchment area, p. 10-17. In: T. Nõges (ed.), Lake Peipsi: meteorology, hydrology, hydrochemistry. Sulemees Publ.

Järvalt A, Kangur A, Kangur K, Kangur, P, Pihu, E, 2004. Fish and fisheries, p. 335-354. In: J. Haberman, E. Pihu and Raukas, A. (eds.), Lake Võrtsjärv. Estonian Encyclopaedia Publ.

Jeppesen E, Jensen JP, Søndergaard M, Lauridsen T, Landkildehus F, 2000. Trophic structure, species richness and biodiversity in Danish lakes: changes along a phosphorus gradient. Freshwater Biol. 45:201-218.

Jeppesen E, Meerhoff M, Holmgren K, González-Bergonzoni I, Teixeira-de Mello F, Declerck SAJ, De Meester L, Søndergaard M, Lauridsen TL, Bjerring R, Conde-Porcuna JM, Mazzeo N, Iglesias C, Reizenstein M, Malmquist HJ, Liu Z, Balayla D, Lazzaro X, 2010a. Impacts of climate warming on lake fish community structure and potential effects on ecosystem function. Hydrobiologia 646:73-90.

Jeppesen E, Mehner T, Winfield IJ, Kangur K, Sarvala J, Gerdeaux D, Rask M, Malmquist HJ, Holmgren K, Volta P, Romo S, Eckmann R, Sandström A, Blanco S, Kangur A, Stabo HR, Tarvainen M, Ventelä A-M, Søndergaard M, Lauridsen TL, Meerhoff M, 2012. Impacts of climate warming on the long-term dynamics of key fish species in 24 European lakes. Hydrobiologia 694:1-39.

Jeppesen E, Moss B, Bennion H, Carvalho L, DeMeester L, Feuchtmayr H, Friberg N, Gessner MO, Hefting M, Lauridsen TL, Liboriussen L, Malmquist HJ, May L, Meerhoff M, Olafsson JS, Soons MB, Verhoeve JTA, 2010b. Interactions of climate change and eutrophication, p. 119-151. In: M. Kerman, R.W. Batterbee and B. Moss (eds.), Climate change impacts on freshwater ecosystems. Wiley-Blackwell.

Kangur A, Kangur P, Kangur K, Möls T, 2007a. The role of tem- perature in the population dynamics of smelt Osmerus eperlanus eperlanus m. spirinchus Pallas in lake Peipsi (Estonia/Russia). Hydrobiologia 584:433-441.

Kangur A, Kangur P, Pihu E, Vaino V, Tambets M, Krause T, Kangur K, 2008. [Fish and fisheries], p. 317-340. In: J. Haberman, T. Timm and A. Raukas (eds.), [Peipsi]. [Book in Estonian]. Eesti Loodusfoto Publ.

Kangur K, Kangur A, Kangur P, Laugaste R, 2005. Fish kill in lake Peipsi in summer 2002 as a synergistic effect of cyanobacterial bloom, high temperature and low water level. P. Est. Acad. Sci. Biol. Ecol. 54:67-80.

Kangur K, Kangur A, Raukas A, 2012. Peipsi lake in Estonia/Russia, p. 596-607. In: L. Bengtsson, R.W. Herschy and R.W. Fairbridge (eds.), Encyclopedia of lakes and reservoirs. Springer.

Kangur K, Milius A, Möls T, Laugaste R, Haberman J, 2002. Lake Peipsi: changes in nutrient elements and plankton communities in the last decade. Aquat. Ecosyst. Health 5:363377.

Kangur K, Möls T, 2008. Changes in spatial distribution of phosphorus and nitrogen in the large north-temperate lowland lake Peipsi (Estonia/Russia). Hydrobiologia 599:31-39.

Kangur K, Möls T, Haldna M, Kangur A, Kangur P, Laugaste R, Milius A, Tanner R, 2003. [Peipsi conservation, biogenesis, water level general dynamics and identification of dangerous situations], p. 73-83. In: T. Frey (ed.), [Considerations on modern ecology]. [Book in Estonian]. Teadusühing IM SAARE.

Kangur K, Park Y.-S, Kangur, A, Kangur P, Lek S, 2007b. Patterning long-term changes of fish community in large shallow lake Peipsi. Ecol. Model. 203:34-44.

Lammens EHRR, 2001. Consequences of biomanipulation for fish and fisheries. FAO Fisheries Circular No. 952. FAO ed., Roma: 23 pp.

Lammens EHRR, Möls T, Kangur K, Melnik M, 2007. Comparison of phosphorus concentrations, chlorophyll- $a$ and transparency between lakes IJsselmeer, Peipsi and Pihkva, p. 81-101. In: M. van Eerden, H. Bos, L. van Hulst (eds.), In the mirror of a lake. Rijkswaterstaat Centre of Water Management Publ.

Laugaste R, Nõges T, Nõges P, Jastremskij VV, Milius A, Ott I, 2001. Algae, p. 31-49. In: E. Pihu and J. Haberman (eds.), Lake Peipsi: flora and fauna. Sulemees Publ.

Lehtonen H, 1996. Potential effects of global warming on northern European freshwater fish and fisheries. Fisheries Manag. Ecol. 3:59-71.

Mäemets H, Palmik K, Haldna M, Sudnitsyna D, Melnik M, 2010. Eutrophication and macrophyte species richness in the large shallow North-European lake Peipsi. Aquat. Bot. 92:273-280

Möls T, 2005. [Linear statistical methods for Estonian freshwater water bodies]. [Book in Estonian]. Estonian Naturalists' Society, Tartu: $256 \mathrm{pp}$.

Moss B, 2007. Shallow lakes, the water framework directive and life. What should it all be about? Hydrobiologia 584:381394.

Moss B, Kosten S, Meerhoff M, Battarbee RW, Jeppesen E, Mazzeo N, Havens K, Lacerot G, Liu Z, De Meester L, Paerl H, Scheffer M, 2011. Allied attack: climate change and eutrophication. Inland Waters 1:101-105. 
OECD, 1982. Eutrophication of water, monitoring, assessment and control. Organization for Economic Cooperation and Development ed., Paris: 150 pp.

Parmesan C, 2006. Ecological and evolutionary responses to recent climate change. Annu. Rev. Ecol. Evol. S. 37:637-669.

Parmesan C, Yohe G, 2003. A globally coherent fingerprint of climate change impacts across natural systems. Nature 421:37-42.

Perkins DV, Reiss J, Yvon-Durocher G, Woodward G, 2010. Global change and food webs in running waters. Hydrobiologia 657:181-198.

Persson A, Brönmark C, 2008. Pikeperch Sander lucioperca trapped between niches: foraging performance and prey selection in a piscivore on a planktivore diet. J. Fish Biol. 73:793-808.

Pörtner HO, Peck MA, 2010. Climate change effects on fishes and fisheries: towards a cause-and-effect understanding. J. Fish Biol. 77:1745-1779.

R Development Core Team, 2010. R: A language and environment for statistical computing. Available from: http://www.R-project.org

Reynolds C, Dokulil M, Padisak J, 2000. Understanding the assembly of phytoplankton in relation to the trophic spectrum: where are we now? Hydrobiologia 424:147-152.

SAS Institute Inc., 2008. SAS OnlineDoc 9.2. Available from: http://www.sas.com/

Scheffer M, Carpenter S, 2003. Catastrophic regime shifts in ecosystems: linking theory to observation. Trends Ecol. Evol. 18:648-656.

Semenova NI, 1960. [The reasons of smelt kill in lake Pskov in August 1959]. [Article in Russian]. Scientific-Technical Bulletin GosNIORKH 10:23-24.

Starast H, Milius A, Möls T, Lindpere A, 2001. Hydrochemistry of lake Peipsi, p. 97-131. In: T. Nõges (ed.), Lake Peipsi: meteorology, hydrology, hydrochemistry. Sulemees Publ.

Thackeray SJ, Sparks TH, Frederiksen M, Burthe S, Bacon PJ, Bell JR, Botham MS, Brereton TM, Bright PW, Carvaldo L, Clutton-Brock T, Dawson A, Edwards M, Elliott JM, Harrington R, Johns D, Jones ID, Jones JT, Leech DI, Roy DB, Scott WA, Smith M, Smithers RJ, Winfield IJ, Wanless S, 2010. Trophic level asynchrony in rates of phenological change for marine, freshwater and terrestrial environments. Global Change Biol. 16:3304-3313.

van Densen WLT, 1985. Piscivory and the development of bimodality in the size distribution of $0+$ pikeperch (Stizostedion lucioperca L.). J. Appl. Ichthyol. 1:119-131.

Woodward G, Christensen JB, Olafsson JS, Gislason GM, Hannesdottir ER, Friberg N, 2010a. Sentinel systems on the razor's edge: effects of warming on Arctic stream ecosystems. Global Change Biol. 16:1979-1991.

Woodward GD, Perkins M, Brown L, 2010b. Climate change in freshwater ecosystems: impacts across multiple level of organisation. Philos. T. Roy. Soc. B 365:2093-2106. 